International Journal of Economics, Business and Accounting Research (IJEBAR)

Peer Reviewed - International Journal

Vol-3, Issue-4, 2019 (IJEBAR)

E-ISSN: 2614-1280 P-ISSN 2622-4771

https://jurnal.stie-aas.ac.id/index.php/IJEBAR

\title{
TRIPLE PSYCHO-ORGANIZATIONAL SUPPORTS FOR CHANGE MANAGEMENT PROCESS
}

\author{
Dwi Indriastuti' ${ }^{1)}$, Olivia Fachrunnisa ${ }^{2)}$ \\ Department of Management, Faculty of Economics, Sultan Agung Islamic University \\ Semarang, Indonesia \\ E-mail: $\underline{\text { dwiindriastuti.y@std.unissula.ac.id; olivia.fachrunnisa@unissula.ac.id }}$
}

\begin{abstract}
In this ever-changing era, organizations are required to be able to answer new challenges that will emerge such as globalization, rapid flow of information and rapid technological developments, resulting in increasing demand for quality employees. This forced the organization to be able to manage existing human resources properly and effectively in order to be able to keep up with the flow of change. Therefore, every organization will try to increase the commitment of its employees, especially the commitment to change. Employees are required to have a high commitment in dealing with change and have behaviors that support change, so that they are in accordance with the changing times and demands of the community, so that the organization can still exist and not be abandoned by its users. This study aims to develop a model to find out how to encourage individual behavior support to change by increasing individual commitment to change within an organization. Change oriented leadership, employee adaptability and the internalization of organizational values which we termed as three psycho-organizational supports are indicated as important antecedents to commitment to change, which in turn will encourage individual behavior to support to change. The data was collected from 116 respondents as employees in Statistical Bureau Province, Indonesia. The analytical method uses SEM (Structural Equational Modeling) to test the hypotheses. Sobel Test is used to test the effect of mediating variables in the model. The research findings show that behavior to support change is strongly influenced by individual commitment to change, the higher the individual's commitment to change, the more they will encourage the individual to have behaviors that support change. While individual commitment to change is influenced by several factors such as changeoriented leadership, employee adaptability and organizational values. These three factors have a positive and significant influence on individual commitment to change.
\end{abstract}

Keywords: Change-oriented leadership; employee adaptability; organizational values; commitment to change; behavior to support to change.

\section{Introduction}

Change becomes a natural and natural thing that happens in life. Changes in the environment, the development of times, and the emergence of new needs, requires humans and organizations to be able to make changes in order to answer these challenges and maintain their existence, (Khasali, 2007). Organizations that are able to survive and live are not the strongest but the most adaptive, namely those who always adjust to various changes that exist in their environment.

Human resources are considered as critical factors that contribute to the success of the organization (Dominguez, 2011). According to Othman (2009), strategic use of human resources is needed to overcome various organizational challenges. Therefore, effective human resource 


\section{International Journal of Economics, Business and Accounting Research (IJEBAR)}

Peer Reviewed - International Journal

Vol-3, Issue-4, 2019 (IJEBAR)

\section{E-ISSN: 2614-1280 P-ISSN 2622-4771}

https://jurnal.stie-aas.ac.id/index.php/IJEBAR

management is important for every organization (Juhdi et al., 2011). Managing human resources in an organization can be done in various ways, one of which is to try to improve the ability of commitment, especially commitment to change, this becomes important because it will affect the attitudes and behavior of individuals to support these changes.

Organizational behavior is closely related to attitudes and behaviors of individuals and groups within the organization (Robbins, 2011). Organizations will only change and act through their members, and even most of the collective activities that occur in organizations are the result of combining individual activities within the organization (George \& Jones, 2001). Success in transforming organizations cannot be separated from the commitment of employees and management to implement and make efforts to change in a truly and harmonious manner. One of the successes of this change is marked by an increase in employee behavior that supports changes so that changes can go as expected.

Commitment is one way that can be used by organizations in shaping employee behavior to change and resolve problems of resistance to change (Cummings \& Worley, 2001). Commitment to change is the affective, normative and continuous relationship of employees to comply and support the success of changes that occur in the organization (Elizur and Guttman, 1976). Daif (2011) states that when employees provide changes that occur within the organization and are not worried about it, the employee will support and commit to implement the change. Commitment to change becomes important for every organization that applies change to have a great opportunity to succeed. According to Hercovich and Meyer (2002), commitment to change has three main aspects, namely affective commitment to change, normative commitment to change and continuous commitment to change.

Support from the leadership is one of the factors that influence individuals to be committed, because leadership is a process of influencing or giving examples to followers in achieving organizational goals. Change-oriented leadership is one of the important factors needed by organizations that are undergoing a process of change. Change-oriented organizational leaders will initiate change effectively, so employees will consider their leaders to be trustworthy and will support employees to face change, so employees will be willing to accept and support these changes (Wanberg \& Banas, 2000).

Conceptually, there is a human tendency to reject change, because it forces people to adopt new ways to do things the organization wants (e.g. systems or processes) (Lunenburg, 2010). As a result, employees experience uncertainty and have fears about potential failures in dealing with new situations (Vakola \& Nikolaou, 2005) which then influence attitudes and behavior (Jimmieson, Terry, \& Callan, 2004). Employees with high adaptability are more likely to struggle to complete difficult tasks (for example, organizational change) and not easily give up when obstacles arise during organizational changes (Mieke, 2015). The higher the ability of employees to adapt, the higher the commitment of an employee to change.

Good internalization of organizational values about change has been shown to reduce resistance to change (Paterson \& Cary, 2002). Employees will be more confident and believe that they can follow changes because they have obtained the necessary information regarding the organization's vision, strategy, policies and plans through the internalization of organizational values. Emphasis on internalizing the values of this organization is predicted to change individuals to want to change (Holt et al., 2007). Based on the explanation above, several variables can be identified that determine employee commitment to change, including: (a) change-oriented leadership that encourages and directs employees to find new ways and ideas in work; (b) employee adaptability where employees are able to adapt to the latest technological and scientific developments; and (c) internalization of organizational values, namely by 
International Journal of Economics, Business and Accounting Research (IJEBAR)

Peer Reviewed - International Journal

Vol-3, Issue-4, 2019 (IJEBAR)

E-ISSN: 2614-1280 P-ISSN 2622-4771

https://jurnal.stie-aas.ac.id/index.php/IJEBAR

believing and guided by the values of the organization, making employees committed to change. Employee commitment to change will affect the employee's behavior to support to change. This study will compile a conceptual model that describes the interrelationships between these variables.

\section{Literature Review and Development of Hypotheses}

\subsection{Change Oriented Leadership and Commitment to Change}

The definition of leadership is based on the assumption that leadership can influence and direct employees, facilitate activities and employee relations within a group or organization (Yulk, 2013). In a rapidly changing global world, organizations need change-oriented leadership. Change-oriented leadership is a leader who is able to identify threats and opportunities for the organization in the future, able to make strategies and build new visions, encourage subordinates to be creative and innovative, and have a creative attitude and offer new ideas, and be able to take risks for significant progress (Yulk, 2002). Leadership in change management is a precursor needed to reduce employee resistance to change (CoyleShapiro \& Morrow, 2003). Eby, Adams, Russell, and Gaby (2000) argue that management in this case leaders must be able to create organizational characteristics that are in accordance with the changes so that change can succeed. Change-oriented leadership will influence and direct employees to be committed to the ongoing process of change, so that conditions can support change. This is in accordance with previous research, namely leaders in an organization that is changing will create an atmosphere that is conducive to change conditions (Tetenbaum, 1998). Change-oriented leadership allows a leader to have a big influence on the views and commitment of his employees. Research by Bing Ling, Yue Guo and Dusheng Chen (2018) concluded that there was a significant correlation of changeoriented leadership with employee commitment to change. Change-oriented leaders will encourage employees to have positive beliefs about changes that occur in the organization and are able to influence employees to have a commitment to change.

\section{H1: Change-oriented leadership can encourage individual commitment to change}

\subsection{Employee adaptability and commitment to change}

In the end a successful organizational change depends on the extent to which each employee is willing to adjust their behavior in line with the changes imaginable (Bovey \& Hede, 2001). That is why employee adaptability refers to the degree to which employees are able to cope with, respond to and support changes that affect their individual roles (Grif, n, Neal, \& Parker, 2007, p. 331). Employees with high adaptability are more likely to struggle to complete difficult tasks (for example, organizational change) and not easily give up when obstacles arise during organizational changes (Mieke, 2015). Other research shows that employees who do not have confidence about their ability to deal with change will not have good desires to change (Vakola et al., 2013). Employees who have a commitment to change will give more effort in change projects to build a positive attitude towards change. Thus, it makes sense to conclude that employees with high adaptability are more likely to have a commitment to change higher.

H2: The higher the adaptability of the employee, the higher the commitment to change

\subsection{Organization Values and Commitment to Change}

Organizational values are views / assumptions / beliefs about something that is good or bad, an action or deed is considered appropriate or not, based on consideration both individually and in 
International Journal of Economics, Business and Accounting Research (IJEBAR)

Peer Reviewed - International Journal

Vol-3, Issue-4, 2019 (IJEBAR)

E-ISSN: 2614-1280 P-ISSN 2622-4771

https://jurnal.stie-aas.ac.id/index.php/IJEBAR

an organization (Robbins, 2007). Mike Woodcock \& Dave Francis (1990) describing organizational values is a belief in behavior which is a choice about what is good or bad, important or not important, which shapes the character of an organization. Organizational values play an important role in carrying out activities within the organization. Vision, mission, values and organizational goals need to be conveyed so that employees through the internalization of organizational values so that employees understand the importance of change and want to participate in supporting changes made by the organization.

Good internalization of organizational values about change has been shown to reduce resistance to change (Paterson \& Cary, 2002). Employees will be more confident and believe that they can follow changes because they have obtained the necessary information regarding the organization's vision, strategy, policies and plans through the internalization of organizational values. Emphasis on internalizing the values of this organization, predicted to change individuals to want to change (Armenakis, Bernerth, Pitts, \& Walker, 2007; Holt et al., 2007).

Research by Jyhyun Yang (2005) shows that organizational values have a positive influence on commitment to change. Organizational values can help reduce employee resistance to change. Resistance can be reduced through understanding and implementing organizational values and helping employees see, the vision, mission and goals of the organization that underlie a change.

H3: The more organizational values are applied, the higher individual's commitment to change

\subsection{Commitment to Changes and Behavior Support to Changes}

Kreitner (2014) states that commitment is an agreement to do something for yourself, others, groups or organizations. Employee commitment to change is a drive or mind set that binds an individual to a series of actions that aim to implement and succeed in implementing and changing initiatives (Herscovitch \& Meyer in Gelaidan, 2013). In other words, one of the challenges of organizational change is keeping their employees committed throughout the process of change (Van den Heuvelet al., 2009).

When a person's attitude towards organizational change is positive, it can be said that there is commitment (Coetsee, 1999). Some studies have shown that commitment to organizations contributes to employee motivation, increases employee performance, reduces attendance and ensures that employee turnover rates remain at a minimum level (Coetsee, 1999; Herold, Fedor, Caldwell \& Liu, 2008; Postmes, Tanis \& De Wit, 2001 in Mike Fox, Anticedent of commitment to change, 2015).

Employee commitment to change will affect organizational behavior as indicated by the behavior of its employees. Some literature says that commitment is one of the most important factors influencing employee behavior to support to change (Armenakis, Feild, Holt \& Harris, 2007; Choi, 2011; Cunningham, 2006; Elias, 2009; Herscovitch \& Meyer, 2002). Commitments to change include understanding and trusting employees towards the good goals that the organization wants to achieve so that employees truly make efforts to achieve organizational goals. Achieving the goals of organizational change is also expected to be able to increase the opportunity of employees to achieve their goals within the organization. This common goal makes employees make every effort to ensure that organizational change efforts can succeed. Employees with high commitment to change tend to have behavior to support change, this is consistent with the research conducted by (Jones, 2007) where it was concluded that the commitment to change has a positive relationship with behavior supporting change 
International Journal of Economics, Business and Accounting Research (IJEBAR)

Peer Reviewed - International Journal

Vol-3, Issue-4, 2019 (IJEBAR)

E-ISSN: 2614-1280 P-ISSN 2622-4771

https://jurnal.stie-aas.ac.id/index.php/IJEBAR

H4: The higher the commitment to change it will further encourage individual behavior to support change

\section{Empirical Model}

Based on an in-depth literature review, the conceptual model proposed in this study is like Figure 1. Individual behavior to support change can be achieved if the individual has a high commitment to change. Individual commitment to change will be greatly influenced by leaders who have change orientation, adaptability and values that exist within the organization.

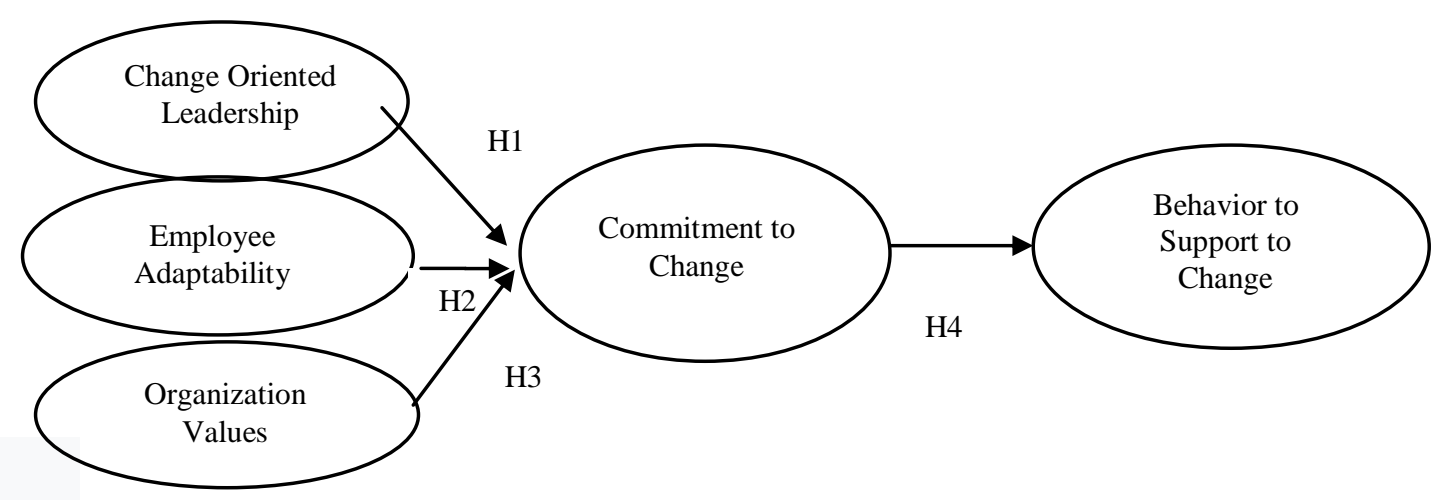

Figure 1. Conceptual Model of the Impact of Commitments to Change to Behavior Supporting Change

Individual commitment to change will encourage individual behavior to support change. Meanwhile, individual commitment to change is influenced by various factors such as changeoriented leadership, adaptability and organizational values. Change-oriented leaders can encourage and influence their subordinates to commit to change. High adaptability makes it easier for employees to struggle to complete difficult tasks (for example, organizational change) and not give up easily when obstacles arise during organizational change, the more able to adapt, the higher the commitment to change. Internalization of good organizational values can increase employee commitment to change according to the wishes and expectations of the organization

\section{Research Methodology}

This research was conducted on 116 respondents using a questionnaire consisting of open questions and closed questions with 5-scale Likert from strongly agree to strongly disagree. Data is analyzed using SEM (Structural Equational Modeling) and Sobel Test.

\section{Measurement}

\subsection{Change Oriented Leadership}

Change oriented leadership is defined as leadership that promotes change, and encourage organizational growth, and generates new ideas in completing work.. We measure this variable with 5 items consist of ability to explain to subordinates the importance of following changes and developments, encourage subordinates to think creatively and find new solutions in completing work, understanding the opportunities and challenges of the organization in the future, willing to take risks and be able to make appropriate and quick decisions related organizational change, and able to establish cooperative relationships with other organizations. The items are adapted from Yukl, Gordin and Taber (2002). 


\subsection{Employee Adaptability}

Employee Adaptability is defined asthe potential underlying employees to behave and be applied effectively in adjusting and anticipating the demands of work, and changes in the environment. We measure this variable with 3 dimensions. The first dimension is Cognitive Adaptation which consists of three indicators, namely the ability to recognize changes in the environment, able to determine what is new and what must be learned and is considered important for effective adaptation, and able to regulate emotions positively from fatigue and saturation. The second dimension is Affective Adaptation which consists of two indicators namely being able to rise from failure and being able to positively regulate emotions from fatigue and saturation. The third dimension is Adaptation Behavior which consists of two indicators, namely proactive behavior, initiating actions that have a positive effect on changing environments and reactive behavior, changing or modifying oneself to better suit the new environment. These items are adapted from Van Dam (2017).

\subsection{Organizational Values}

Organizational Values are defined as the guidelines that an organization has that are believed, trusted, and carried out by employees so that they become the hallmark of the organization. We measure this variable with six items consist of professional, integrity, trustworthy, serving, disciplined, innovative and creative. Professionals are able to work according to the job description that has been given. Integrity is able to work honestly without engineering. Amanah is able to maintain the trust that has been given as well as possible. Serving is able to provide the best service. Discipline is able to work in accordance with applicable rules and regulations. Innovative and creative is able to find new ways and ideas in completing work (taken from the Core Value Organization).

\subsection{Commitment to Change}

Commitment to Change is defined as the drive or desire that binds an individual in a series of actions aimed at implementing and succeeding in the implementation and change initiatives. It consists of three indicators namely affective commitment to change, continuous commitment to change and normative commitment to change. Affective commitment to change is the desire to provide support for change based on the inherent benefits, love and emotional attachment to the work done. Normative commitment to change is the desire to provide support for change, because of the obligation and moral responsibility to provide support for changes to the organization that has employed it. Continuous commitment to change is the desire to provide support for change because of fear of reduced income and loss of employment, if the change process failed. These item are adapted from Herscovitch and Meyer in Chouw (2016).

\subsection{Behavior to Support to Change}

Behavior to Support to Change is defined as the behavior expected by employees as a form of support and effort to achieve the goals of organizational change. Indicators of behavior supporting change consist of three indicators, namely compliance, cooperation and championing. Complience is the willingness of employees to do what is asked of them by the organization in implementing organizational change. Cooperation / cooperation is the willingness of employees to accept the "spirit" of change and to provide input for the success of organizational change. Championing is the willingness of employees to fight for change and sell it to others to change. These item are adapted from Herscovitch and Meyer in Chouw (2016). 
International Journal of Economics, Business and Accounting Research (IJEBAR)

Peer Reviewed - International Journal

Vol-3, Issue-4, 2019 (IJEBAR)

E-ISSN: 2614-1280 P-ISSN 2622-4771

https://jurnal.stie-aas.ac.id/index.php/IJEBAR

\section{Results and discussion}

\subsection{Structural Equation Models Analisys (SEM)}

Based on the results of lisrel, Multivariate, Normal, variables, indicators, not fulfilled, therefore, to overcome them by using the estimation model based on Maximum Possibility and making corrections to bias by adding asymptotic covariance matrix to the input data (Ghozali, 2008: 250).

\subsubsection{Preliminary Analysis Estimates}

All indicators observed in this study have good validity and reliability values, this is indicated by its reliability construct value (CR) greater than 0.70 and its variance extracted value (VE) is greater than 0.50 (Igbaria et al in Wijanto, 2008). Therefore all observed indicators are included in the next SEM model.

\subsubsection{Test of the Compatibility of the Overall Model (Fit Overall Models)}

Test the suitability of the whole model between data and models, can be seen in Table 1.

Tabel 1 Overall Test Result

\begin{tabular}{|c|c|c|c|c|}
\hline No & $\begin{array}{c}\text { GOF } \\
\text { Measureme } \\
\text { nt }\end{array}$ & Degree of Goodness & Estimation & Result \\
\hline (1) & $(2)$ & (3) & $(4)$ & $(5)$ \\
\hline 1. & $\begin{array}{l}\text { Chi-Square } \\
\text { p-value }\end{array}$ & $\begin{array}{l}\text { Small value } \\
\mathrm{p}>0.05\end{array}$ & $\begin{array}{l}\text { Chi-Square }=25,15 \\
\mathrm{p}=0.0\end{array}$ & Not good \\
\hline 2. & NCP interval & $\begin{array}{l}\text { Small value, narrow } \\
\text { interval }\end{array}$ & $\begin{array}{l}33,23 \\
17,43 ; 56,47\end{array}$ & good \\
\hline 3. & RMSEA & RMSEA $\leq 0.08$ & RMSEA $=0.00$ & good \\
\hline 4. & ECVI & close ECVI saturated & $\begin{array}{l}M^{*}= \\
S^{*}=0,26 \\
I^{*}=4,97\end{array}$ & good \\
\hline 5. & AIC & close AIC saturated & $\begin{array}{l}\mathrm{M}^{*}=60,23 \\
\mathrm{~S}^{*}=30,00 \\
\mathrm{I}^{*}=571,89\end{array}$ & good \\
\hline 6. & CAIC & close CAIC saturated & $\begin{array}{l}M^{*}=105,27 \\
S^{*}=86,30 \\
I^{*}=590,64\end{array}$ & good \\
\hline 7. & NFI & $\mathrm{NFI} \geq 0.90$ & 0.94 & good \\
\hline 8. & NNFI & $\mathrm{NNFI} \geq 0.90$ & 0.80 & Marginal fit \\
\hline 9. & CFI & $\mathrm{CFI} \geq 0.90$ & 0.94 & good \\
\hline 10. & IFI & IFI $\geq 0.90$ & 0.94 & good \\
\hline 11 & RFI & $\mathrm{RFI} \geq 0.90$ & 0.89 & Marginal fit \\
\hline 12. & $\mathrm{CN}$ & $\mathrm{CN} \geq 200$ & 37,02 & Not good \\
\hline 13. & RMR & $\begin{array}{l}\text { Standardized RMR } \leq \\
0.05\end{array}$ & 0.11 & Not good \\
\hline 14. & GFI & $\mathrm{GFI} \geq 0.90$ & 0.86 & Marginal fit \\
\hline 15. & AGFI & $\mathrm{AGFI} \geq 0.90$ & 0.31 & Not good \\
\hline
\end{tabular}


International Journal of Economics, Business and Accounting Research (IJEBAR)

Peer Reviewed - International Journal

Vol-3, Issue-4, 2019 (IJEBAR)

E-ISSN: 2614-1280 P-ISSN 2622-4771

https://jurnal.stie-aas.ac.id/index.php/IJEBAR

$\mathrm{M}^{*}=$ Model, $\mathrm{S}^{*}=$ Saturated, $\mathrm{I}^{*}=$ Independent

Of the 12 GOF sizes above, there are 4 not good, 3 marginal fit and 7 have a good match, so it is concluded that the model is good.

\subsubsection{Effects of Change Oriented Leadership, Employee Adaptability and Organizational Value on Commitment to Change and Behavior to Support to Change}

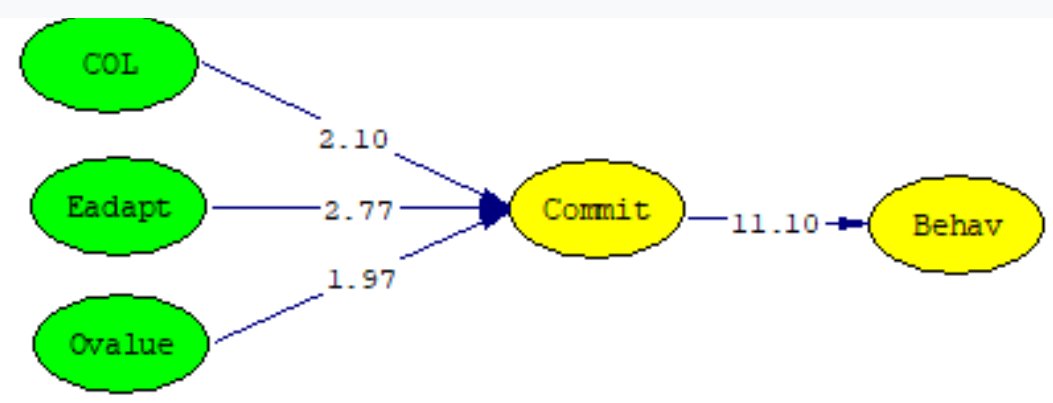

Figure 1 Path diagram and structural equation showing the relationship between Change Oriented Leadership, Employee Adaptability, and Organizational Value to Commitment to Change and Behavior to support to change.

\section{Structural Equations :}

(1) Commit $=0,21 * \mathrm{COL}+0.36 *$ Eadapt $+0.23 *$ Ovalue,

Errorvar $=0.43$

$\mathrm{R}^{2}=0.56$

t-values $=2,10 ; 2,77 ; 1,97 ; 6,34$

(2) Behav $=0,73 *$ Commit,

Errorvar $=0,46$

$\mathrm{R}^{2}=0,53$

$\mathrm{t}$-values $=11,10 ; 6,63$

\subsection{Test Results of Hypotheses}

\section{Hypothesis 1 Test Results}

Hypothesis I of this study is that good leadership is able to encourage commitment to change. Equation (1) above shows the relationship between variables Change Oriented Leadership, Employee Adaptability, and Organizational Value towards Commitment to Change. The path parameter coefficient obtained from the relationship between change oriented leadership variables to commitment to change is 0.21 with a t-statistic value of 2.10 . This value is more than 1.96 at the alpha significance level of 0.05 so that with a confidence level of 95 percent it can be said that there is a significant effect between change oriented leadership on commitment to change. The positive value of the parameter coefficient means that the better the changeoriented leadership, the higher the commitment to change. So that hypothesis 1 is supported.

\section{Hypothesis 2 Test Results}


International Journal of Economics, Business and Accounting Research (IJEBAR)

Peer Reviewed - International Journal

Vol-3, Issue-4, 2019 (IJEBAR)

E-ISSN: 2614-1280 P-ISSN 2622-4771

https://jurnal.stie-aas.ac.id/index.php/IJEBAR

Hypothesis 2 of this study is that the higher the adaptability of employees, the higher the commitment to change. The path coefficient obtained from the relationship between the employee adaptability variable to commitment to change is 0.36 with a t-statistic value of 2.77 . This value is more than 1.96 at the alpha significance level of 0.05 so that with a 95 percent confidence level it can be said that there is a significant influence between employee adaptability to commitment to change. Positive value of the parameter coefficient means that the higher the adaptability of an employee, the higher the commitment to change. So hypothesis 2 is supported.

\section{Hypothesis 3 Results}

Hypothesis 3 of this research is that the more Organizational values are applied, the higher the commitment to change. The path coefficient obtained from the relationship between organizational values variable to commitment to change is 0.23 with a t-statistic value of 1.97 . This value is more than 1.96 with an alpha significance level of 0.05 so that with a confidence level of 95 percent it can be said that there is a significant effect between organizational values to commitment to change. The positive value of the parameter coefficient means that the values of the organization are implemented properly, the commitment to change will be higher. So hypothesis 3 is supported.

\section{Hypothesis Test Results 4}

The research hypothesis 4 is that the higher the commitment to change it will further encourage individual behavior to support change. Based on equation (2) the path coefficient obtained from the relationship between commitment to change to the behavior to support to change is 0.73 with a t-statistical value of 11.10. This value is more than 1.96 with an alpha significance level of 0.05 with a confidence level of 95 percent. It can be said that there is a significant influence between the commitment to change to the behavior to support to change. The positive value of the parameter coefficient means that the higher the commitment to change, the better the behavior of supporting change. So that hypothesis 4 is supported.

\subsection{Test mediation with Sobel Test}

Sobel test is used to test how much the role of mediating variables in this case Commitment to change mediates the effect of Change Oriented Leadership, Employee Adaptability, and Organizational Value on Behavior to support to change.

\section{Commitment to Change mediates Change Oriented Leadership towards Behavior to support to change \\ Based on equation (1) it can be seen that the coefficient value of a is 0.21 with a standard error of 0.10 , and coefficient of $\mathrm{b}$ is 0.73 with a standard error of 0.066 using the $\mathrm{z}$ value of the single test obtained value of 2.06 , this value is greater than the value of $\mathrm{z}$-score 1.96 so it can be concluded that change-oriented leadership can encourage behavior to support change by increasing the commitment of employees to change first}

\section{Commitment to Change mediates Employee Adaptability to Behavior to support to change}

Based on equation (1) it can be seen that the coefficient value of a is 0.36 with a standard error of 0.14 , and coefficient of $b$ is 0.73 with a standard error of 0.066 using the $z$ value of the single test obtained value of 2.50 , this value is greater than the value of $\mathrm{z}$-score 1.96 so it can be concluded that the ability of employees to adapt can encourage behavior to support change by increasing the commitment of employees to change first. 


\section{Commitment to Change mediates Organizational Value to Behavior to support to change}

Based on equation (1) it can be seen that the coefficient value of a is 0.23 with a standard error of 0.11 , and coefficient of $b$ is 0.73 with a standard error of 0.066 using the $z$ value of a single test obtained value of 2.05, this value is greater than the value of z-score 1.96 so that it can be concluded that organizational values can encourage behavior to support change by increasing the commitment of employees to change first.

\subsection{Discussion}

Behavior to support change is strongly influenced by commitment to change. While the commitment to change positively and significantly is influenced by change-oriented leadership, the ability of employees to adapt and organizational values. The ability of employees to adapt has the most dominant influence on commitment to change compared to other variables, especially the ability to rise from failure. The ability to adapt from employees is an important factor in an organization, greatly determines the success of the change itself. Employees with high adaptability are more likely to struggle to complete difficult tasks (for example, organizational change) and not easily give up when obstacles arise during organizational changes (Mieke, 2015).

Change-oriented leadership has a dominant influence on commitment to change, especially the ability to explain to subordinates the importance of following change and development. The element of leadership in Central Java Province BPS is expected to give greater attention to employees by providing examples of attitudes and behaviors and exemplary efforts to deal with change so that employees can increase commitment to change. This result is consistent with the research conducted by Bing Ling, Yue Guo and Dusheng Chen (2018) which concluded that there was a significant correlation of change-oriented leadership with employee commitment to change.

Employee adaptability has a positive effect on commitment to change, especially the ability of employees to rise from failure. This is reinforced by the open-ended questions in the questionnaire that most employees have persistence, tenacity and confidence in overcoming problems that occur. Employees have effective ways to overcome failure, including not ashamed to ask questions and discuss with superiors or other colleagues when they fail at a job, want to learn from various sources of information such as through the internet or relevant literature. Therefore, every BPS employee in Central Java province is expected to have a high ability to adapt by utilizing a variety of available resources so that in the end it can make the individual more ready to face changes. This is consistent with the research conducted by Van Dam (2017) where employees who have high adaptability will be better prepared to face change

Organizational values also influence the committee to change, especially the values of integrity, trustworthiness and friendly service. Integrity is the values to be able to be honest, open, and without engineering. Amanah is a proof of an employee's accountability to God Almighty which is able to maintain the trust that has been given by the organization as well as possible. Whereas serving in a friendly manner is a form of social responsibility in a society where an ASN must have the attitude of serving rather than being served, able to serve the demands and demands of the community for fast and quality data needs with great hospitality. This result is consistent with the research conducted by Jyhyun Yang (2005) which shows that organizational values have a positive influence on commitment to change. 
International Journal of Economics, Business and Accounting Research (IJEBAR)

Peer Reviewed - International Journal

Vol-3, Issue-4, 2019 (IJEBAR)

E-ISSN: 2614-1280 P-ISSN 2622-4771

https://jurnal.stie-aas.ac.id/index.php/IJEBAR

Commitment to change is the most dominant variable in influencing behavior supporting change, especially affective commitment and normative commitment. Therefore commitment to change must be increased in order to encourage behavior to support change. This is consistent with the research conducted by (Jones, 2007) that commitment to change has a positive relationship with behaviors supporting change

\section{Conclusion}

Based on the results of data analysis and discussion that has been described in the previous chapters, it can be concluded that to encourage the behavior to support to change in this change era, the organization must prepare commitment to change, how to prepare individuals to change with 3 (three) variables which are: change-oriented leadership, employee ability to adapt (and organizational values)

\section{Manajerial Implication}

Some suggestions that arise are that leaders give more examples and examples in everyday attitudes and behavior. Leaders are expected to be more consistent between words and actions, because essentially the leader is a role model for his subordinates. In addition, based on the results of the study, it is not expected, decisions can be made, and if not, BPS will be moved by data users, along with the emergence of data of today's startups.

The superior management team is always focused on educating its human resources so that it can reduce and saturate. Because of the assistance provided and agreed commitments, their commitment to productive work can be transferred. Management can provide a place to relax where musical instruments, massage chairs, and aroma therapy are available which can improve mood and also the enthusiasm of employees who can return to productive work. In addition, do light stretches for all employees at certain hours. This simple movement will help the body keep working in the office. It is also necessary to do Gathering outside the city besides being able to strengthen family ties within the organization and can also provide a new atmosphere that can eliminate boredom.

Management is needed to improve the ability to create and innovate for workers to be better prepared to make changes, among others by providing training - which can support work that requires training using stata software, amos, reviews, lisrel (for data analysis), corel and photoshop.

Giving rewards and awards from leaders to employees who managed to carve out achievements and success is important, because it can increase individual commitment to be changed. Employees will be encouraged to follow changes because there are prizes they will receive if they can change according to the organization's goals. Appreciation from leadership can be either financial or non-financial. This form of financial appreciation can be in the form of additional incentives or bonuses, while the form of non-financial appreciation is in the form of promotions for receipts, awards and awards.

The management can create a discussion group consisting of leaders and employees, this is needed to ask for input from subordinates about what things still need to be done during the change process. Involve employees involved in decision making and have a place to receive input and suggestions for the change process. In addition, managers also need to carry out motivational training, and capacity building on a regular basis, hoping to foster motivation and ability of employees, make employees more confident and eager to learn new things, so that they can promote sports for innovation and creativity during this is considered still lacking. 
International Journal of Economics, Business and Accounting Research (IJEBAR)

Peer Reviewed - International Journal

Vol-3, Issue-4, 2019 (IJEBAR)

E-ISSN: 2614-1280 P-ISSN 2622-4771

https://jurnal.stie-aas.ac.id/index.php/IJEBAR

\section{Research Limitations}

The weakness of this research, there was a self-response bias to measure change support variables.

\section{Future research}

Future research will be more valid if supporting supporting variables are asked directly by the supervisor rather than the respondent, but questioning the questionnaire cannot be anonymous because it will be matched with the discussion of the behavior of the immediate supervisor.

Acknowledgments: Our thanks go to BPS (or Biro Pusat Statistik; en: Central Bureau of Statistics) of Central Java Province for providing full support from the beginning to the end of this study.

\section{References}

Bovey, W.H. and Hede, A. (2001), "Resistance to organisational change: the role of defencemechanisms", Journal of Managerial Psychology, Vol. 16 No. 7.Education, lnc., Upper Saddle River, New Jersey, pp. 209- 586.

Chou, P (2016). The effect Of Support on Employee's Behavioral Support For Organizational Change An Empirical Study in Taiwan. International Journal of Economic, Commerce and Management, Vol . IV Issue 2, 22-41.

Daif, K (2011). Change in Higher Learning Institution: Lecturers Commitment to Organizational Change (C2C). International of Business and Social Science Vol. 2 No. 21; November 2011.

Gelaidan, H.M. (2013). The Factor Effecting Employee to Change in Public Sector: Evidence from Yemen. International Business Reaserch Vol 6, No. 3, 2013.

Herscovitch, L., \& Meyer, J. P. (2002). Commitment to organizational change: Extension of a three-component model. Journal of Applied Psychology, 87.

Jones, L. M. (2007). An Examination of Social Influence Effects on Commitment to Change and Implementation Behaviors. Disertasi. Departement of Management at the Kenan-Flagler Business School

Khasali, R. (2007). Re-code Your Change DNA. Jakarta: Gramedia Pustaka Utama

Liu, Y. (2010). When Change Leadership Impacts Commitment to Change And When It Doesn't: A Multi-level Multi Dimensional Investigation. Disertasi. Georgia Institute of Technology.

Robbins, S.P. (2011). Perilaku Organisasi Edisi 12. Jakarta: Salemba Empat.

Vakola, M, Tsaousis, I. \& Nikolaou, I., (2004), The Effect of Emotional Intelligence and Personality Variables on Attitudes toward Organizational Change, Journal of Managerial Psychology, Vol. 19 No.2, pp. 88-110 
International Journal of Economics, Business and Accounting Research (IJEBAR)

Peer Reviewed - International Journal

Vol-3, Issue-4, 2019 (IJEBAR)

E-ISSN: 2614-1280 P-ISSN 2622-4771

https://jurnal.stie-aas.ac.id/index.php/IJEBAR

Van Dam, Karen. (2017), Employee adaptability to change at work: a multidimensional, resource-based framework, https:/www.cambridge.org/core/terms. https://doi.org/10.1017/ CBO9781139096690.009

Vurgun \& Oztop. (2011), Significance of Values for Management and Organizational Culture. Suleyman Demirel University The Journal of Faculty of Economics and Administrative Sciences Y.2011, Vol.16, No.3, pp.217-230.

Yang, J. (2005). The Relationship of The Organisational Culture, Commitment to Change and to Behavioral Support for Organizational Change in Taiwan. Disertasi. Nova Southeastern University

Yukl G Gordon A \& Taher (2002), A Herarchical Taxonomy of Leadership Behavior Integrating a Half Century of Behavior Research. Journal of Leadership and Organizational Studies, 1532.

Yukl, G. (2013), Leadership in Organizations, Pearson, Boston 